\title{
Neurophysiological comparative response to clinical and surgical treatment of the ulnar neuropathy in leprosy
}

\section{Padrões neurofisiológicos da resposta tardia ao tratamento clínico e cirúrgico da neuropatia ulnar na hanseníase}

\author{
Marianna Cossi Monseff Borela ${ }^{1}$, Milton Cury Filho ${ }^{2}$, Daniel Rocco Kirchner ${ }^{3}$, Manuel Henrique Salgado ${ }^{4}$, (D) Marcos da Cunha \\ Lopes Virmond ${ }^{5}$, Dosé Antonio Garbino ${ }^{6}$
}

${ }^{1}$ Former student of Clinical Neurophysiology Education Programm, Instituto Lauro de Souza Lima - ILSL

2 Hand Surgeon, Professor of Clinical Neurophysiology Education Programm, Instituto Lauro de Souza Lima - ILSL

3 Professor of Clinical Neurophysiology Education Programm, Instituto Lauro de Souza Lima - ILSL

${ }^{4}$ School of Engineery, Universidade Estadual Paulista "Júlio de Mesquita Filho"

${ }^{5}$ Hand Surgeon, Professor School of Medicine, Faculdade Nove de Julho - UNINOVE

6 Coordinator of Clinical Neurophysiology Education Programm, Instituto Lauro de Souza Lima - ILSL

\section{Corresponding}

José Antonio Garbino

E-mail: ja.garbino@gmail.com

Submitted: June 24, 2020

Accepted: Ocutber 6, 2020

\section{How to cite}

Borela mcm, Cury Filho M, Kirchner DR, Salgado $\mathrm{MH}$, Virmond MCL, Garbino JA. Neurophysiological comparative response to clinical and surgical treatment of the ulnar neuropathy in leprosy. Acta Fisiatr. 2020;27(3):125-130.

DOI: 10.11606/issn.2317-0190.v27i3a166868

\begin{abstract}
Leprosy neuropathy may develop into subacute and chronic inflammatory scenarios, called reactions, which may cause entrapments in the anatomic tunnels. Objective: This study describes the late nerve conduction findings in patients with ulnar neuropathy at the elbow that were submitted to clinical and surgery treatments. Methods: A total of 27 nerves of 21 patients with borderline leprosy during type 1 (reversal) reaction were selected in a non- competing retrospective cohort for three years. The nerves with treated clinically active neuropathy (Group A1) were randomized for inclusion of surgical treatment (Group A2) after one month of clinical treatment without clear signs of clinical and neurophysiological improvement. Fifteen nerves were randomly chosen for surgery while 12 were clinically treated, after steroids treatment without expected response. Nerve conduction was measured before and after treatment on four occasions. Results: The authors observed significant improvement in the following variables in the surgically treated nerves: compound motor action potential amplitude (CMAP) at elbow and above elbow and conduction velocity (CV) along the forearm. Conclusion: The improvement of CMAP amplitudes and conduction velocity (CV) along the forearm express the late effect of nerve decompression. Persistence of temporal dispersion (TD) along the elbow was related to the new reaction or to incomplete surgical solution. However, moderate reduction in CV along the elbow, without TD, was considered an indication of na expected partial remyelination. Previous gradation of the nerve lesion based on the CMAP amplitude was related to the most severe results.
\end{abstract}

Keywords: Ulnar Neuropathies, Leprosy, Neural Conduction

\section{RESUMO}

A neuropatia de hanseníase pode desenvolver quadros inflamatórios subagudos e crônicos denominados reações, os quais podem evoluir para compressões nos túneis anatômicos. Objetivo: Descrever os achados de condução nervosa (CN) tardios em pacientes com neuropatia ulnar no cotovelo submetidos aos tratamentos clínico e cirúrgico. Método: Vinte e sete nervos de 21 pacientes foram selecionados em uma coorte retrospectiva não-concorrente por um a três anos, sendo formados dois grupos. Após o tratamento clínico sem sinais inequívocos de melhora os nervos foram randomizados para manter o tratamento clinico (Grupo A1) ou adicionar a descompressão do nervo (Grupo A2). Resultados: Os autores observaram melhora significativa nas seguintes variáveis no Grupo A2, tratado com a adição da descompressão cirúrgica, amplitude do potencial de ação motor composto (PAMC) no cotovelo e acima do cotovelo e velocidade de condução (VC) ao longo do antebraço. Conclusão: O ganho em amplitudes dos PAMCs no cotovelo e acima do cotovelo e da velocidade de condução (VC) ao longo do antebraço são a expressão do efeito tardio da descompressão do nervo ulnar. A persistência de dispersão temporal (DT) através do cotovelo foi relacionada a nova reação ou solução cirúrgica incompleta. Entretanto, a persistência de redução moderada da VC através do cotovelo sem a DT foi discutida e considerada como remielinização parcial esperada. A graduação previa da lesão do nervo baseada na amplitude dos PAMCs apresentou relação direta aos resultados menos favoráveis.

Palavras-chave: Neuropatias Ulnares, Hanseníase, Condução Nervosa 


\section{INTRODUCTION}

Leprosy neuropathy, after multidrug therapy, can develop acute inflammatory phenomena called reactions, that in nerves are denominated neuritis. ${ }^{1}$ In leprosy there are two types of reaction episodes: type 1 (T1R) and type 2 (T2R).

The T1R occurs mainly in borderline tuberculoid (BT), borderline borderline (BB) and borderline lepromatous (BL) cases. Except for the tuberculoid (TT) patients, T1R lasts approximately six months. ${ }^{1,2}$ The second type occurs in lepromatous (LL) and BL cases, lasting for approximately one month, with a higher frequency of recurrences that, may be classifed as chronic type 2 reaction. ${ }^{2}$

These acute inflammatory episodes can compromise nerve trunks in an isolated manner, i.e. - mononeuropathy, in situations that have a low bacillary load (TT or BT), or affect more than one nerve, i.e., in cases with a heavy bacillary load (BB, BL and $L L)$. These reactional episodes present exuberant symptoms, acute and subacute demyelination and even axonal loss and they are recurrent and dependent on adequate management. ${ }^{1,2}$

Treatment with oral steroids is the primary choice for treating neuritis, and during its development the entrapment of the nerve by neighboring structures in the anatomical tunnels must be considered. ${ }^{1-3}$

The most frequently affected nerve in the upper limb is the ulnar in the elbow tunnel, followed by the median in the wrist, the superficial radial in the wrist and less frequently the radial at the elbow, above the supinator arcade. ${ }^{1}$ In the lower limbs, the most commonly involved nerves are the tibial in the tarsal tunnel, rarely above, followed by the fibular nerve in the retrofibular tunnel, besides the sensory branches: saphenous, superficial peroneal and sural. ${ }^{1}$

Early neurophysiological findings show focal demyelinating features such as reduction of conduction velocity, increase in the duration of the motor waves, i.e., Temporal Dispersion (TD), and increase of the distal latencies. Among these parameters, Temporal Dispersion is related to subacute demyelination and, consequently, neuropathy with inflammatory activity during reactions. ${ }^{3}$

During progression the disease can lead to axonal degenerations and the motor conduction exam will show motor waves with low amplitudes. ${ }^{1,3}$

Neurophysiological findings after the neuritis treatment, despite being well described in the acute period, ${ }^{2}$ are rarely studied in its late period. This study describes the late treatment outcome of the ulnar nerve motor conduction parameters in patients with leprosy neuropathy, treated clinically and surgically.

\section{OBJECTIVE}

1. To Assess the motor nerve conduction (NC) parameters of the ulnar nerve in patients that went through leprosy neuropathy treatment, in order to describe and compare the late (1-3 years) responses in clinically treated nerves (group A1) versus surgically treated nerves (group A2).

2. To identify the neurophysiological parameters that may have predictive function in both groups.

\section{METHOD}

A randomized trial to determine the role of nerve decompression in leprosy patients focusing the ulnar nerve was carried out during a period of one to three years after the beginning of the treatment in the Clinical Neurophysiology department of the Instituto Lauro de Souza Lima (ILSL), Brazil.

Patients with clinical and neurophysiological active ulnar neuropathy, i.e. Nerve-function assessment (NFA): graded sensory testing and voluntary muscle testing and NC studies deterioration during the follow-up, ${ }^{3}$ were included. It was considered a clinically active neuropathy if the last complaint of the patient related to the ulnar nerve was made within the last six months.

Patients at risk of a neuropathy other than leprosy neuropathy were excluded, i.e. diabetes, alcoholism, HIV infection, also with family history of hereditary neuropathy were excluded.

The selected nerves with treated clinically active neuropathy (Group A1) were randomized for inclusion in the surgical treatment (Group A2) after one month of clinical treatment $^{3}$ without clear signs of clinical and neurophysiological improvement. The non-operated nerves (Group A1) and the operated nerves (Group A2) composed the study subgroups for NC comparisons.

\section{Neurophysiological examination}

A Nihon Kohden MEB-9200J electromyograph was used for the nerve conduction studies carried out by the Neurophysiology team and supervised by the staff tutors.

The chosen neurophysiologic parameters were: compound motor action potential (CMAP), distal latency (DL), conduction velocity (CV), the across elbow temporal dispersion (TD) and the $\mathrm{F}$ wave assessed before treatment, during the evolution and at the last evaluation.

In the motor nerve conduction study, the surface electrodes were placed in the following way: the active (G1) over the belly of abductor digiti minimi and the reference electrode (G2) in a neutral position over the base of the first phalange, on a tendon or a bone surface. ${ }^{4}$

The stimulation was done at $8 \mathrm{~cm}$ proximally to the $\mathrm{G} 1 \mathrm{on}$ the forearm; the second stimulation placed at the elbow, approximately $2 \mathrm{~cm}$ below, and the third, $11 \mathrm{~cm}$ above the second stimulation point. The conduction velocity over the forearm segment and across the elbow was computed.

The CMAP temporal dispersion (TD), i.e., the duration of CMAP, was measured below and above the elbow and its propotional values, were summed. The minimum value of the $F$ wave latency, related to demyelination in all segments of the nerve from stimulating electrode to spine and back to the recording electrode, was measured over a series of 16 stimuli. During the procedure the limb was kept relaxed and the elbow was placed at an inclination of 130-140 degrees. ${ }^{2}$ The body temperature was controlled above $32-34{ }^{\circ} \mathrm{C} .{ }^{4}$

The neurophysiological criteria for activity was the acute or subacute demyelination, i.e. Compound Motor Action Potential (CMAP) temporal dispersion more than $50 \%$ and a conduction velocity (CV) reduction to less than $30 \%$ of the normal lower limit. ${ }^{5,6}$ The criteria to consider the conduction block as an 
acute demyelination was a CMAP amplitude reduction of more than $30 \%$ in the proximal CMAP(s) compared to distally placed sites, but without temporal dispersion. ${ }^{5,6}$

The severity of the selected nerves was arbitrarily classified based on the distal CMAP amplitudes, as follows: Pronounced: $<1 \mathrm{mV}$, Moderate: 1-2 mV, and Slight: $>2 \mathrm{mV}$. Patients with comorbidities and steroid contraindications were excluded.

A special technique of NC was used in order to detect the anatomic variation of Martin-Gruber (MG), recording the CMAP in the first interossei dorsalis and stimulating in median and ulnar at wrist and elbow each one. ${ }^{7}$ The MG variation has high prevalence and can simulate conduction disturbs, mainly the conduction block at the elbow or above. ${ }^{8,9}$

\section{Surgical technique}

In order to decompress the involved nerves, a standard surgical technique was used following Duerksen ${ }^{10}$ (1994); Sirinivasan \& Palande ${ }^{11}$ (1997) and Huang et al. ${ }^{12}$ (2004).

Such principles include the following aspects:

- The fibrous ligaments release must be always performed (Osborne ligament at the cubital tunnel).

- Epineurotomy is allowed only in the areas with thickened and opaque epineurium. This procedure must be performed under $4 \mathrm{X}$ magnification using microsurgery instruments. The thin and translucent epineurum should not be opened.

- Preferably, the ulnar nerve must be maintained in place after the ligament release. Only the spontaneous subluxation of the nerve outwards from the ulnar tunnel during the passive elbow flexion, as tested by the surgeon, can indicate an anterior transposition of the nerve if it has developed strong fibrosis. In case of a still supple nerve a stabilization plasty over the cubital tunnel is preferred.

\section{Statistics}

The differences among each variable were compared with the best in the moments: the pre-treatment exam, in the period of $>6$ months to 1 year and 2 to 3 years. Other two nerves $(n=2)$ with pronounced and complete lesions were analyzed separately. For inter-group analysis were used the Mann-Whitney test and Pearson's correlation coefficient for neurophysiologic parameters analysis.

\section{RESULTS}

A total of 27 nerves in 21 patients were selected, 16 men and five women from 29 to 62 years old with ulnar neuropathies. Fifteen nerves were included in Group A2 and 12 in Group A1, all patients were classified as BB with T1R.

There were no significant differences among the recorded nerve conduction parameters compared between the randomized nerves for surgery and for clinical treatment, which indicates that the samples were similar.

The CMAPs amplitudes in the last evaluation presented significant differences in the stimulation sites along the ulnar nerve, at the elbow and above elbow, except in the wrist, for the surgically treated nerves (Group A2), (Table 1). For these analyzes, the values of CMAP amplitudes at the elbow of two nerves with MG anastomosis were excluded.
Table 1. Results of all variables during pre-treatment and final evaluation, Group A1 was composed of 12 nerves and Group A2 of 15 nerves

\begin{tabular}{lcccccc}
\hline \multicolumn{1}{c}{$\begin{array}{c}\text { Mean values } \\
\text { Variables/subgroups }\end{array}$} & A1 & A2 & p-value & 1 - 3 years (6a) & \\
& DL & & A1 & A2 & -value \\
\hline CMAP wrist & 4.09 & 3.58 & 0.42 & 3.61 & 3.38 & 0.59 \\
CV forearm & 5.6 & 4.68 & 0.42 & 5.92 & 4.92 & 0.38 \\
CMAP elbow & 44.18 & 46.44 & 0.73 & 44.91 & 49.92 & 0.46 \\
CV across elbow & 2.56 & 3.52 & 0.46 & 2.81 & 4.86 & $\mathbf{0 . 0 4}$ \\
CMAP above elbow & 29.52 & 33.88 & 0.18 & 33.41 & 36.75 & 0.32 \\
TD across elbow & 2.15 & 3.04 & 0.4 & 2.57 & 4.39 & $\mathbf{0 . 0 5}$ \\
F wave & 95.9 & 45.3 & 0.08 & 48.9 & 46.3 & 0.74 \\
\hline
\end{tabular}

Legend: distal latencies ( $D L)$, compound motor action potential (CMAP), conduction velocity $(C V)$, temporal dispersion (TD) and $F$ wave, its mean values, and the statistical comparisons pre-treatment and last evaluation in clinically- treatead (A1) and surgically- treated nerves (A2)

Positive correlation was also found for the CV in the forearm in surgically treated nerves between the $4^{\text {th }}$ and $6^{\text {th }}$ (last) evaluation $(p=0.027)$. Significant alterations in the TD and $F$ waves were not found, but the TDs presented improvement, i.e. reduction in the CMAP duration, or stabilization of the TDs averages during the follow-up, (Table 2). The tendency line shows a reduction for surgically treated nerves $(p=0.08)$ comparing the first and last evaluations, (Figure 1).

Table 2. Temporal Dispersion (TD) in surgically treated and clinically treated nerves

\begin{tabular}{lccc}
\hline $\begin{array}{l}\text { TD across elbow } \\
\text { follow-up }\end{array}$ & $\begin{array}{c}\text { Surgical subgroup } \\
(\mathbf{n}=\mathbf{1 3})\end{array}$ & $\begin{array}{c}\text { Clinical subgroup } \\
(\mathbf{n}=\mathbf{1 2})\end{array}$ & Total \\
\hline improved & 7 & 4 & 11 \\
stable & 4 & 6 & 10 \\
worsened & 2 & 2 & 4 \\
\hline The $(n=25)$ is because two nerves had no neurophysiologic response detectable at
\end{tabular}

the beginning and kept this status during the follow-up

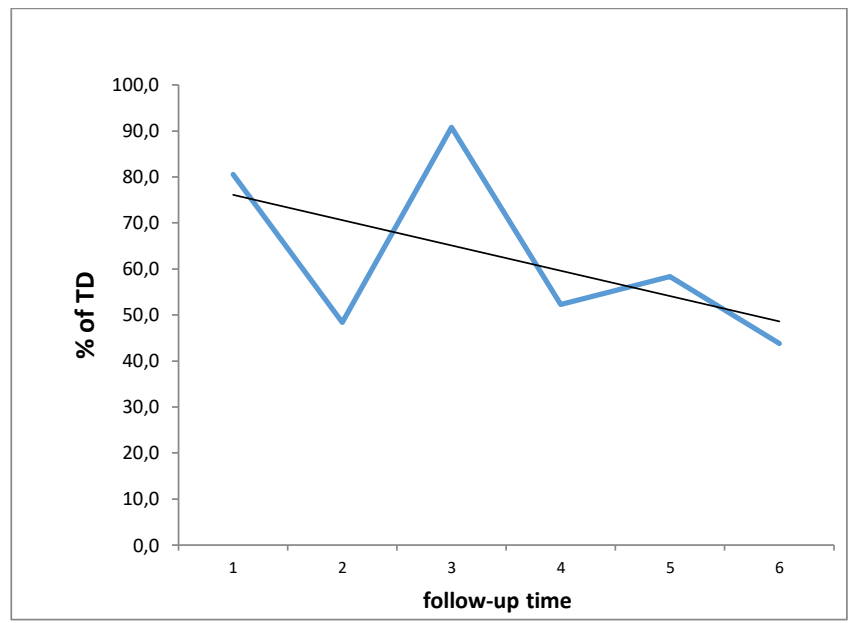

Figure 1. The tendency line of the TD above elbow average during the follow-up comparing surgically treated and clinically treatead nerves, though it was not statically significant $(p=$ 0.08)

There were no significant alterations in the upper arm CV, $\mathrm{CV}$ through the elbow, and $\mathrm{F}$ waves (Table 1). There were no 
significant differences observed among the velocities through the elbow during the entire evaluation period, and the operated and non-operated nerves also did not differ in this parameter.

The values of the $\mathrm{CV}$ remained around $30 \mathrm{~m} / \mathrm{s}$ (average: 36 $\mathrm{m} / \mathrm{s}$, minimum: 23.9 and maximum: $57.9 \mathrm{~m} / \mathrm{s}$ ) at the end of the sequences. Three distinctive types of conduction were observed across the elbow: (i) CV reaching normal values (three nerves); (ii) presence of constant CV values, averaging $36 \mathrm{~m} / \mathrm{s}$, and (iii) constant average CV values of $36 \mathrm{~m} / \mathrm{s}$ associated to the increased TD, (Figure 2).

\section{Results in nerves with absent motor response}

The two nerves with complete and pronounced lesions with absent motor response remained without detectable motor response during the follow-up until the last evaluation.

\section{Results of TD in all nerves}

The four nerves, in which the TD worsened during the follow-up, were clinically and laboratorially evaluated according to the ILSL protocol ${ }^{13}$ for the suspicion of relapse i.e. defined as the multiplication of $M$. leprae, suspected by the increase in the $\mathrm{BI}$, or new reaction usually with evidence of clinical deterioration in both cases:

a) Clinically treated nerves: a female, 60, and a male, 43 years old, were diagnosed as T1R "late reaction".

b) Surgically treated nerves: a Male, 29, and a female, 52 years old, without signs of reaction in the skin in the dermatological clinical and laboratorial examination.
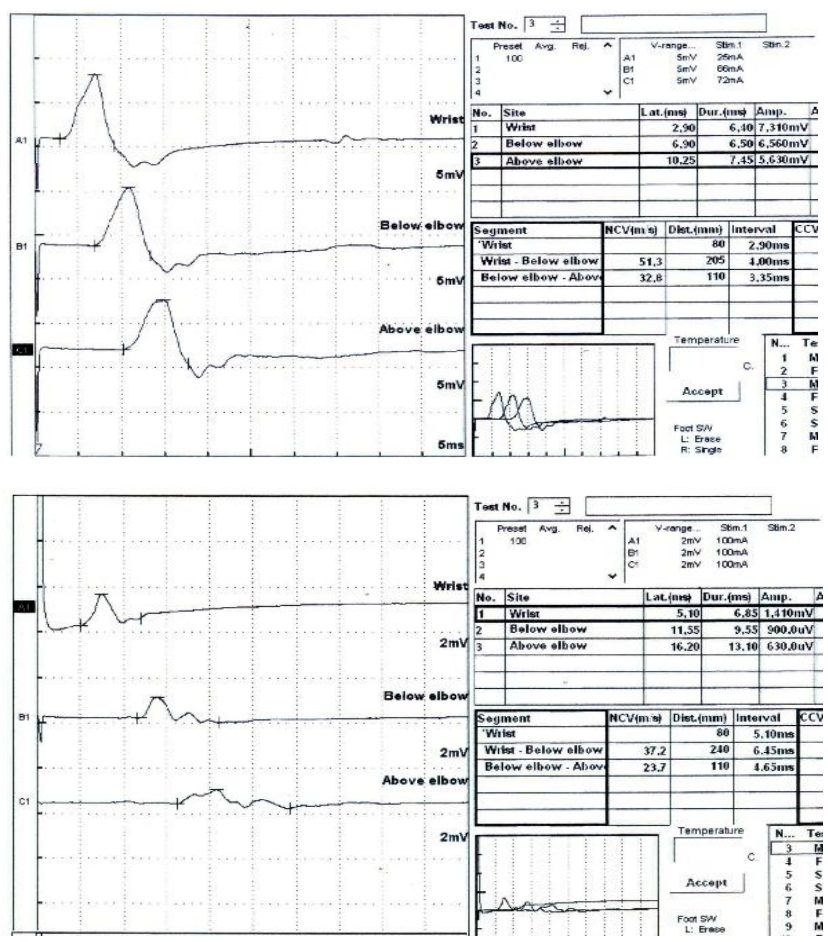

TD. a) The presence of the $C V$ in the average values of $36 \mathrm{~m} / \mathrm{s}(23.9$ to $57 \mathrm{~m} / \mathrm{s}$ ), and b) The $C V$ in these values added to a high value of $T D$, comparing the CMAP duration above the elbow to the duration at the wrist: $48 \%$

Figure 2. In this Figure the record exemplify a recovered nerve a) and b) an unrecovered nerve that remains

\section{DISCUSSION}

The results showed a significant increase of the CMAPs amplitudes in the surgically treated nerves in the elbow and above elbow, between the first and the last evaluation (Table 1). The CMAP amplitude improved in all studied nerve segments, except for the wrist which was not statistically significant. Therefore, CMAPs amplitudes showed being the most sensible neurophysiologic parameter to demonstrate nerve recovery.

A significant improvement of the CV in the forearm was observed between the fourth and last evaluation, without differences of the CV across the elbow. The improvement of the $\mathrm{CV}$ along the forearm indicates remyelination, which was predominant in the surgically treated nerves, $p=0.027$. Therefore, this finding can be considered an unequivocal consequence of nerve decompression.

The improvement of the TD through the elbow was expected, as it has been noted in other studies during neuritis treatment. ${ }^{6}$ An improvement was observed in this study, but it did not have statistical support, $p=0.08$, (Figure 1 ).

According to Table 1 TD worsened in four nerves, while in 10 other nerves the TD was stable, indicating that in the four worsened nerves newer demyelinating activity are taking place..$^{5,6}$ In two of the clinically-treated patients, the presence of type I reaction was confirmed, being one of the unfavorable factors in the long term follow-up of leprosy neuropathy. In two surgically-treated patients, an anterior subluxation of the ulnar nerve during the elbow flexion has been clinically observed.

These results suggest that the ulnar nerve transposition procedure should be considered in the surgical strategy. ${ }^{14}$ Therefore, during the follow-up in a treated nerve, the presence of increased TD must be investigated in its etiology for a new reaction, a relapse leprosy or a non-solution of the entrapment.

As the ulnar elbow tunnel is the epicenter of the compressive phenomenon, usually presenting a more pronounced demyelination, a limited remyelination in this segment is expected. The incomplete remyelination with a thin myelin sheathing the axons is observed in the histopathological studies of the regenerating nerves. ${ }^{15,16}$

This morphological trait may be explained by a reduced competence in the conversion of myelinated and nonmyelinated Schwann cells to a cell specialized to promote repair and insufficiency in the formation of regeneration tracks for directing axons to their targets. ${ }^{17}$

The values of the CV around 30 to $40 \mathrm{~m} / \mathrm{s}$, average: $36 \mathrm{~m} / \mathrm{s}$, without TD at the end of the sequences highlights a "residual" situation of incomplete nerve remyelination in leprosy after the neuritis by reaction and compression, (Figure 2). Therefore, it can be assured that these values of CV, but without TD, do not necessarily mean that there is inflammatory activity in the nerve. The severity degree, based on the difference between the average values of the CMAP at the beginning and the values at the final evaluation, showed that the pronounced degrees had negative variation, but the mean CMAP amplitude variation did not show statistical significance amid them $(p=$ 0.074), (Figure 3).

Only in the nerves classified as slight, a positive variation was observed. This variation may reflect a trend to better 
prognosis of nerve improvement with decompression and may be indicate early decompression. Burns et al. ${ }^{18}$ in a multicenter study looking for outcomes after single decompression, noted that the association of the disease duration and previous nerve function were potentially important predictors.

Analyzed separately, the two nerves with complete lesion that did not present any recovery in the follow-up suggest that these findings are indicative of the most negative outcomes. The lack of axonal regeneration in these two nerves could be caused by the extensive presence of intraneural fibrosis, which would inhibit the progression of the axonal sprouting through the tubes of the endoneurum. ${ }^{19}$
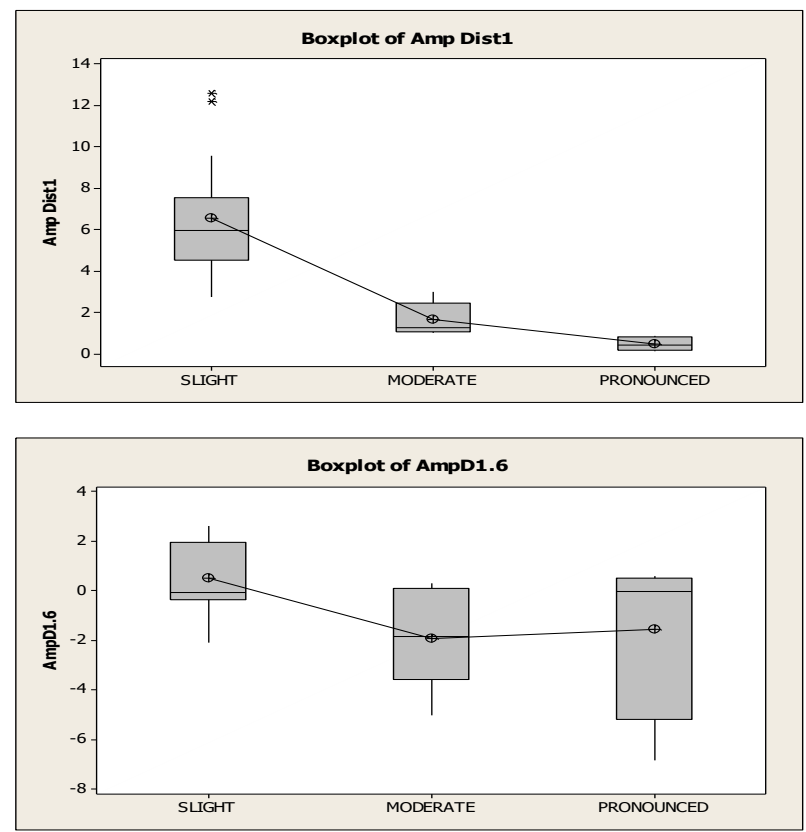

a) the previous average of the CMAP amplitudes, i.e., in the first evaluation, graduated in slight, moderate and pronounced, and b) the comparison of the sixth over the first evaluation averages of the CMAP amplitudes, showing that the degree pronounced had negative variation, despite the mean of the CMAP amplitudes didn't show statistical significance $(p=0.074)$ considering $5 \%$ the level of significance for any group

Figure 3. CMAP amplitude

\section{CONCLUSION}

The surgically treated nerves had superior neurophysiological responses along the ulnar nerve, bellow and above the entrapment site, statistically significant when compared with the clinically treated nerves. The pronounced severity degree and the nerves without motor responses have shown a trend in prediction of negative neurophysiological outcome.

\section{REFERENCES}

1. Garbino JA, Marques Jr W . A neuropatia da hanseníase. In: Alves ED, Ferreira TL, Ferreira IN (Org.). Hanseníase: avanços e desafios. Brasília: Editora UnB; 2014. p. 215-29.

2. Garbino JA, Virmond MCL, Ura S, Salgado MH, Naafs B. A randomized clinical trial of oral steroids for ulnar neuropathy in type 1 and type 2 leprosy reactions. Arq. Neuropsiquiatr. 2008;66(4):861-7. Doi: https://doi.org/10.1590/S0004-282X2008000600016
3. Garbino JA, Heise CO, Marques W Jr. Assessing nerves in leprosy. Clin Dermatol. 2016;34(1):51-8. Doi: https://doi.org/10.1016/i.clindermatol.2015.10.018

4. Preston DC, Shapiro BE. Basic nerve conduction studies. In: Preston DC, Shapiro BE. Electromyography and neuromuscular disorders: clinical-electrophysiologicultrasound correlations. 4th ed. Philadelphia: Elsevier; 2020. p. 23-40.

5. Tankisi H, Pugdahl K, Fuglsang-Frederiksen A, Johnsen B, Carvalho $M$, Fawcett PR, et al. Pathophysiology inferred from electrodiagnostic nerve tests and classification of polyneuropathies. Suggested guidelines. Clin Neurophysiol. 2005;116(7):1571-80.

https://doi.org/10.1016/i.clinph.2005.04.003

Doi:

6. Garbino JA, Naafs B, Ura S, Salgado $\mathrm{MH}$, Virmond $\mathrm{M}$. Neurophysiological patterns of ulnar nerve neuropathy in leprosy reactions. Lepr Rev. 2010;81(3):206-15.

7. Uchida $Y$, Sugioka $Y$. Electrodiagnosis of Martin-Gruber connection and its clinical importance in peripheral nerve surgery. J Hand Surg Am. 1992;17(1):54-9. Doi: https://doi.org/10.1016/0363-5023(92)90113-4

8. Almeida JA, Vitti M, Garbino JA. Estudo anatômico da anastomose de Martin-Gruber. Hansen Int. 1999;24(1):1520.

9. Kimura J. Fatos e falácias nos estudos de neurocondução. In: Kimura J. Eletrodiagnóstico em doenças de nervos e músculos: princípios e aspectos práticos. 4 ed. Rio de Janeiro: DiLivros; 2015. p. 211-41.

10. Duerksen F. Tratamento cirúrgico da neurite hansênica. In: Duerksen F, Virmond M. Cirurgia reparadora e reabilitação em hanseníase. Bauru: Instituto Lauro de Souza Lima; 1997. p. 107-18.

11. Srinivasan $H$, Palande DD. Essential surgery in Leprosy techniques for district hospitals. Geneve: WHO; 1997.

12. Huang JH, Samadani U, Zager EL. Ulnar nerve entrapment neuropathy at the elbow: simple decompression. Neurosurgery. 2004;55(5):1150-3. Doi: https://doi.org/10.1227/01.neu.0000140841.28007.f2

13. Barreto J A, Carvalho CV, Cury Filho M, Garbino JA, Nogueira MES, Soares CT. Hanseníase multibacilar com baciloscopia dos esfregaços negativa: a importância de se avaliar todos os critérios antes de defi nir a forma clínica. Hansen Int. 2007;32(1): 75-9.

14. Dellon AL. Multiple Crush Concept Applied to Multiple Nerves in Leprous Neuropathy. Clin Podiatr Med Surg. 2016;33(2):203-17.

https://doi.org/10.1016/j.cpm.2015.12.009

15. Andrade PR, Jardim MR, Silva AC, Manhaes PS, Antunes SL, Vital $R$, et al. Inflammatory Cytokines Are Involved in Focal Demyelination in Leprosy Neuritis. J Neuropathol Exp Neurol. 2016;75(3):272-83. Doi: https://doi.org/10.1093/inen/nlv027

16. Mietto BS, Andrade PR, Jardim MR, Antunes SL, Sarno EN. Demyelination in Peripheral Nerves: Much to Learn from Leprosy Neuropathy. J Mult Scler. 2016;3(2):174. Doi: https://doi.org/10.4172/2376-0389.1000174

17. Jessen KR, Mirsky R. The repair Schwann cell and its function in regenerating nerves. J Physiol. 2016;594(13):3521-31. Doi: https://doi.org/10.1113/JP270874 
18. Burns PB, Kim HM, Gaston RG, Haase SC, Hammert WC, Lawton JN, et al. Predictors of functional outcomes after simple decompression for ulnar neuropathy at the elbow: a multicenter study by the SUN study group. Arch Phys Med Rehabil. 2014;95(4):680-5.

Doi: https://doi.org/10.1016/j.apmr.2013.10.028
19. Antunes SL, Chimelli L, Jardim MR, Vital RT, Nery JA, CorteReal $S$, et al. Histopathological examination of nerve samples from pure neural leprosy patients: obtaining maximum information to improve diagnostic efficiency. Mem Inst Oswaldo Cruz. 2012;107(2):246-53. Doi: https://doi.org/10.1590/s0074-02762012000200015 